DOI: $10.2478 / \mathrm{v} 10014-012-0016-1$

Agrovoc descriptors: water balance, groundwater, lysimeters, evapotranspiration, measuring instruments, equipment, meteorological instruments, plant cover, water use, precipitation, resource management, water management, water resources, water pollution, groundwater pollution

Agris category code: $\mathrm{p} 10$

\title{
Determination of water balance components with high precision weighing lysimeter in Kleče
}

\author{
Vesna ZUPANC ${ }^{1}$, Reinhard NOLZ ${ }^{2}$, Peter CEPUDER ${ }^{2}$, Branka BRAČIČ - ŽELEZNIK $^{3}$, Marina PINTAR ${ }^{1}$
}

Received August 30, 2012; accepted September 28, 2012.

Delo je prispelo 30. avgusta 2012, sprejeto 28. septembra 2012.

\begin{abstract}
Components of the basic water balance equation and water balance calculation for July 2011 for weighing lysimeter on water supply pumping station in Kleče, Ljubljana the presented. Lysimeter and outflow mass measured with high precision weighing cells and precipitation as determined from changes in the mass of the lysimeter were used in calculation. Precipitation measurements in the same time resolution as the lysimeter mass measurements would be needed for correct calculation of actual evapotranspiration. In time of high plant water requirements only substantial precipitation events directly contribute to immediate groundwater recharge. The low water retention of the aquifer sediments shows susceptibility of the aquifer to ground water pollution.
\end{abstract}

Key words: weighing lysimeter, water balance, lysimeter station

\section{IZVLEČEK}

\author{
DOLOČITEV ČLENOV VODNE BALANCE Z \\ NATANČNIM TEHTALNIM LIZIMETROM V \\ KLEČAH
}

Obravnavani so členi in izračun osnovne enačbe za vodno balance za julij 2011 za tehtalni lizimeter na črpališču pitne vode Kleče v Ljubljani. Pri izračunu so bile uporabljene meritve mase lizimetra in iztoka, merjene $\mathrm{z}$ natačnimi tehtalnimi celicami ter padavin, izračunane iz spremembe mase lizimetra. $\mathrm{Za}$ pravilen izračun dejanske evapotranspiracije bi bile potrebne meritve padavin $\mathrm{v}$ enakem časovnem razkoraku kot potekajo meritve na tehtalnem lizimetru. V času visoke porabe vode s strani rastlinskega pokrova $\mathrm{k}$ bogatitvi podtalnice prispevajo le večji, zaporedni padavinski dogodki. Nizke zadrževalne sposobnosti sedimentov vodonosnika kažejo občutljivost vodonosnika in ogroženost podzemne vode zaradi onesnaženja.

Ključne besede: tehtalni lizimeter, vodna bilanca, lizimetrska postaja

\section{INTRODUCTION}

Lysimeters are used for the measurement of amount and quality of water percolation beneath plant's root zone, water loss via evapotranspiration, as well as numerous ranges of applications in agriculture and environment (Meissner et al., 2010). Quantification of soil water flow is a prerequisite for accurate prediction of solute transfer within the unsaturated zone (Meissner et al., 2010) providing answers to both scientific and practical questions regarding protection of groundwater and groundwater recharge.

\footnotetext{
Biotechnical faculty, p.p.2995, 1001 Ljubljana, vesna.zupanc@bf.uni-lj.si

2 Institute of Hydraulics and Rural Water Management, University of Natural Resources and Life Sciences, Vienna, Austria

${ }^{2}$ Drinking Water and Sewerage System Public Utility, Ljubljana, Slovenia
} 
Practical application of groundwater models for urban water management can be hampered by the lack of knowledge of the complex urban groundwater recharge patterns (Vižintin et al., 2010). Groundwater from Ljubljansko polje aquifer, which is in the center of Slovenia, is fresh water source for the 270000 inhabitants of Slovenia's capital (Vižintin et al., 2010). Above the aquifer intensive vegetable production is ongoing in close proximity to or even within the protected groundwater zone, posing a threat to groundwater quality (Zupanc et al., 2011).
In the recent years lysimetry has evolved significantly and improved techniques, which enable accurate measurements of water flow and water balance parameters (Meissner et al., 2010, von Unold and Fank, 2008), and can be used for investigating hydrological processes such as precipitation, infiltration, or deep percolation with respect to groundwater recharge.

In this article we address water balance for July 2011 by using data from the lysimeter station in Ljubljana Kleče, and some of the challenges arising from calculation and data interpretation.

\section{MATERIALS AND METHODS}

Lysimeter station in Ljubljana Kleče Water Pumping station was constructed in the eighties for the water balance measurements (Brilly and Gorišek, 1985), however outflow measurements indicated structural damage (Zupanc et al., 2005). In 2010 a new and technically advanced weighing lysimeter was installed at the drinking water pumping station in Ljubljana Kleče, Slovenia (308 $\mathrm{m}$ altitude, $46^{\circ} 5^{\prime} 11^{\prime}$ ' $\mathrm{N}, 14^{\circ} 29^{\prime} 56^{\prime}$ ' E), that enables stateof-the-art measurements of water balance parameters. The type of lysimeter is a scientific lysimeter (von Unold and Fank, 2008), designed to solve the water balance equation by measuring the mass of the lysimeter monolith as well as that of outflow tank with high accuracy and high temporal resolution. The soil monolith $(2 \mathrm{~m}$ height, surface area $1 \mathrm{~m}^{2}$ ) was taken from sandy gravel sediments on the area of the water pumping station (Fluvisol), plant cover is extensive grass. The lysimeter weighing facility detects mass changes as small as $30 \mathrm{~g}$, which corresponds to a water head of 0.03 $\mathrm{mm}$. Inside the monolith T8 tensiometers and TDR Trime probes were installed to measure soil water status, namely soil water tension $(\mathrm{hPa})$ and soil water content $(\%)$, respectively (Table 1, Figure 1). In addition, water sampling from monolith horizons under field conditions is possible to describe the solute fluxes inside the soil profile (von Unold and Fank, 2008). Figure 1 shows the structure of the lysimeter facilities (lysimeter vessel, outflow tank, pump, and data logger), and data management processes, as well as the lysimeter bottom boundary conditions subroutine. The latter is necessary in order to adapt the water dynamics inside the lysimeter as a closed system to the conditions in an undisturbed field soil profile. Outflow water is collected with suction cups and pumped into outflow storage tank. Boundary conditions are controlled through soil water status (soil water tension, Figure 1) on the bottom of the lysimeter and in the field on the same depth $(190 \mathrm{~cm})$. If necessary, water is pumped back into the lysimeter to maintain the same soil water status. Total water mass of the full outflow tank is $30 \mathrm{~kg}$, drainage capacity is $20 \mathrm{~kg}$, boundary conditions water supply $10 \mathrm{~kg}$. 
Table 1: Hydrological quantities measured on the lysimeter station in Kleče, Ljubljana

\begin{tabular}{l|l|c|c}
\hline & \multicolumn{1}{|c|}{ Parameter } & Units & Time step \\
\hline Weighing Lysimeter & Water tension - lysimeter $(50,100,150,190 \mathrm{~cm})$ & $\mathrm{hPa}$ & $10 \mathrm{~min}$ \\
2010 & Water tension - field $(190 \mathrm{~cm})$ & $\mathrm{hPa}$ & $10 \mathrm{~min}$ \\
& Water content $(50,100,150 \mathrm{~cm})$ & $\mathrm{Vol} \%$ & $10 \mathrm{~min}$ \\
& Soil temperature - lysimeter $(50,100,150,190 \mathrm{~cm})$ & ${ }^{\circ} \mathrm{C}$ & $10 \mathrm{~min}$ \\
& Soil temperature - field $(190 \mathrm{~cm})$ & ${ }^{\circ} \mathrm{C}$ & $10 \mathrm{~min}$ \\
& Lysimeter mass & $\mathrm{kg}$ & $1 \mathrm{~min}$ \\
& Outflow tank mass & $\mathrm{kg}$ & $1 \mathrm{~min}$ \\
\hline Environmental & Precipitation & $\mathrm{mm}$ & $24 \mathrm{~h} \mathrm{sum}$ \\
Agency of Slovenia & & & \\
\hline
\end{tabular}

Components of the basic water balance equation for the lysimeter are precipitation $(P)$, outflow $(O)$, evapotranspiration $(E T)$ and change of water in the monolith $(\Delta S)$, written as

$P-E T-O-\Delta S=0$

If the lysimeters' mass is recorded in certain time steps, with precipitation and outflow amount measured separately, actual evapotranspiration can be deduced from their mass change (Young et al. 1996). $E T_{a}$ should then be calculated after

$E T_{a}=\left(P_{i+1}-P_{i}\right)-\left(W_{i+1}-W_{i}\right)-\left(O_{i+1}-O_{i}\right)$, (2)

where $E T_{a}$ is actual evapotranspiration $(\mathrm{mm})$, $P_{i}$ precipitation $(\mathrm{mm}), W_{i}$ lysimeter mass $(\mathrm{kg})$ and $O_{i}$ mass of the outflow tank $(\mathrm{kg}), i$ is the time step. All quantities should have the same temporal resolution. $W$ and $O$ were measured at the lysimeter facility in 1-minute-intervals (Table 1). $P$ was measured on-site $\left(P_{\text {site }}\right)$, and at the meteorological station of the Environmental Agency of Slovenia (ARSO) in Ljubljana $\left(P_{\text {city }}\right)\left(299 \mathrm{~m}\right.$ altitude, $46^{\circ} 3^{\prime} 57^{\prime}$ ' $\mathrm{N}$, $14^{\circ} 31$ '2' E) with standard pluviograph, which gives the sum of precipitation for 24 hours (from $7 \mathrm{am}$ to $7 \mathrm{am}$ ). Therefore $E T_{a}$ was determined on a daily base using Eq. 2, with $i$ being $24 \mathrm{hrs}$.
Furthermore, $P$ was determined directly from the lysimeter weighing data $\left(P_{\text {lys }}\right) . P_{\text {lys }}$ was calculated by first determining positive $W$ change with the help of graph, then subtracting $W$ immediately before mass increase from the maximum $W$ before the latter began decreasing (which is due to either $E T$ or $O$ ). The basic approach is that in short time intervals either $P$ (positive mass change) or ET (negative mass change) occur, with $O$ being taken into account (von Unold and Fank, 2008). Obviously, this method can provide only an estimation of $P$, because during rainfall also evaporation and transpiration take place, which can have significant influence if precipitation event is small and the surface hot. Due to high spatial variability of the storms (Barros and Lettenmeier, 1994), measurements on lysimeter's micro location is necessary. Weighing lysimeters with the same precision have given good results for dew measurements (Meissner et al., 2007, Xiao et al., 2009), and they deliver proper results if $P$ from standardized pluviographs is not representative (remote location), malfunctioning or inadequate in terms of temporal resolution of measurements.

Reference evapotranspiration $\left(E T_{0}\right)$ was calculated by ARSO according to FAOPenman-Monteith (Allen et al., 1998) based on weather data from the meteorological station in Ljubljana (299 $\mathrm{m}$ altitude, $46^{\circ} 3^{\prime} 57^{\prime}$ ' $\mathrm{N}$, $14^{\circ} 31^{\prime 2}{ }^{\prime \prime}$ E). 


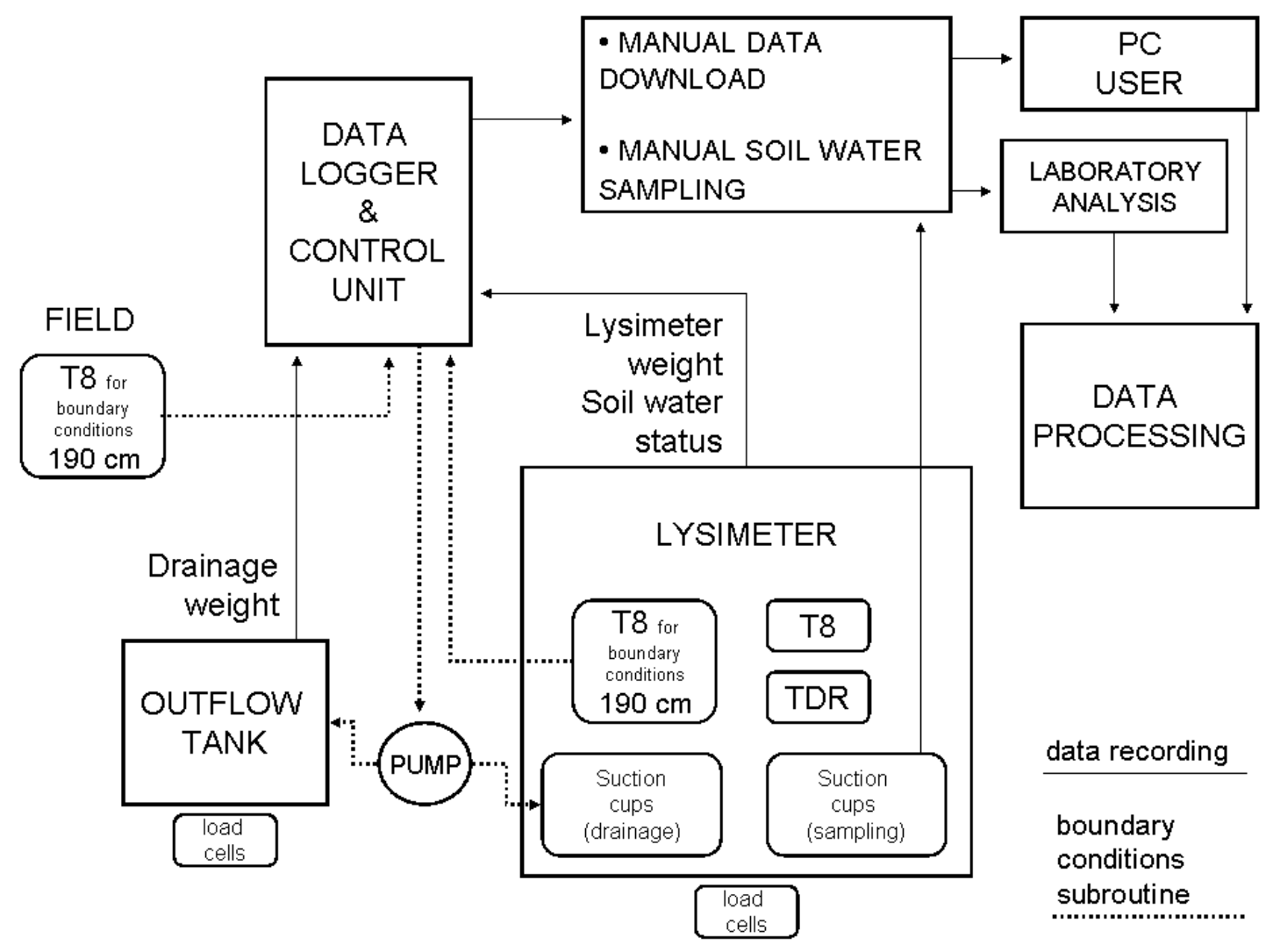

Figure 1: Flow chart of Kleče weighing lysimeter station elements and sensors, as well as data transfer and storage

\section{RESULTS AND DISCUSSION}

Figure 2 shows the mass changes of the lysimeter monolith and the outflow tank. The mass of the lysimeter was between $4030.6 \mathrm{~kg}$ (minimum on the $17^{\text {th }}$ of July) and $4219.9 \mathrm{~kg}$ (maximum on the $24^{\text {th }}$ of July, Figure 2) representing a change in profile water content of about $190 \mathrm{~mm}$. Outflow was about $130 \mathrm{~mm}$ in the same period. Based on the mass changes 15 precipitation events were determined (Figure 2, Table 2), two substantial: one on the $17^{\text {th }}$ of July and a second on the $23^{\text {th }}$ of July. Total monthly precipitation amount was $246.5 \mathrm{~mm}$. The precipitation from $22^{\text {nd }}$ to $24^{\text {th }}$ of July caused high outflow - the outflow tank was emptied six times - that lasted for several days and disguised the subsequent precipitation event on the $27^{\text {th }}$ of July $(3.9 \mathrm{~mm}$, as determined from the data). The amount of monthly outflow was about $60 \%$ of the rainfall in July.

The pluviograph on the lysimeter station delivered no data $\left(P_{\text {site }}\right)$ after $23^{\text {rd }}$ of July (Table 2 ), presumably malfunction occurred due to high intensity of the event. Namely, precipitation event on the $23^{\text {rd }}$ of July begun at $20: 17(W=4076.6 \mathrm{~kg}$, Figure 2$)$ and lasted until 22:09 $(W=4134.7 \mathrm{~kg}$, Figure 2$)$ with high intensity $\left(31.1 \mathrm{~mm} \cdot \mathrm{h}^{-1}\right)$ that was observed for example in precipitation events in Julian Alps (Žagar et al., 2004), then after a short break continued until the next day at 8:08 $\left(W_{\max }=4219.9 \mathrm{~kg}\right)$ with lower intensity $\left(8.5 \mathrm{~mm} \cdot \mathrm{h}^{-1}\right)$ (Figure 2). Measurements from the ARSO meteorological station $\left(P_{\text {city }}\right)$ were significantly different, thus they were not 
representative. Consequently, actual $E T_{\mathrm{a}}$ was calculated using $P_{\text {lys. }}$

The first half of July was hot and dry with an average $E T_{0}$ of $5.4 \mathrm{~mm}$ per day. In the same period, $E T_{a}$ was always lower with an average of $4.5 \mathrm{~mm}$ per day (Table 2). An explanation for the differences is that $E T_{0}$ was calculated using data from the ARSO meteorological station in the city (ca. $4 \mathrm{~km}$ away), and micro climatic conditions of the Kleče lysimeter station differ due to the surrounding forrest. It is also possible that the differences between calculated $E T_{0}$ and measured $E T_{a}$ are that the grass cover does not fulfill the requirements for comparing Penman-Monteith calculation (Allen et al., 2011).

The second half was affected from several rainfall events as mentioned before. $E T_{a}$ exceeded $E T_{0}$ after rainfall, likely due to interception and evaporation losses. On $23^{\text {rd }}$ and $24^{\text {th }}$ the water balance resulted in improper negative $E T_{a}$. This problem should be solved by optimizing interpretation of outflow data, especially at high outflow rates with several emptying processes of the outflow tank.

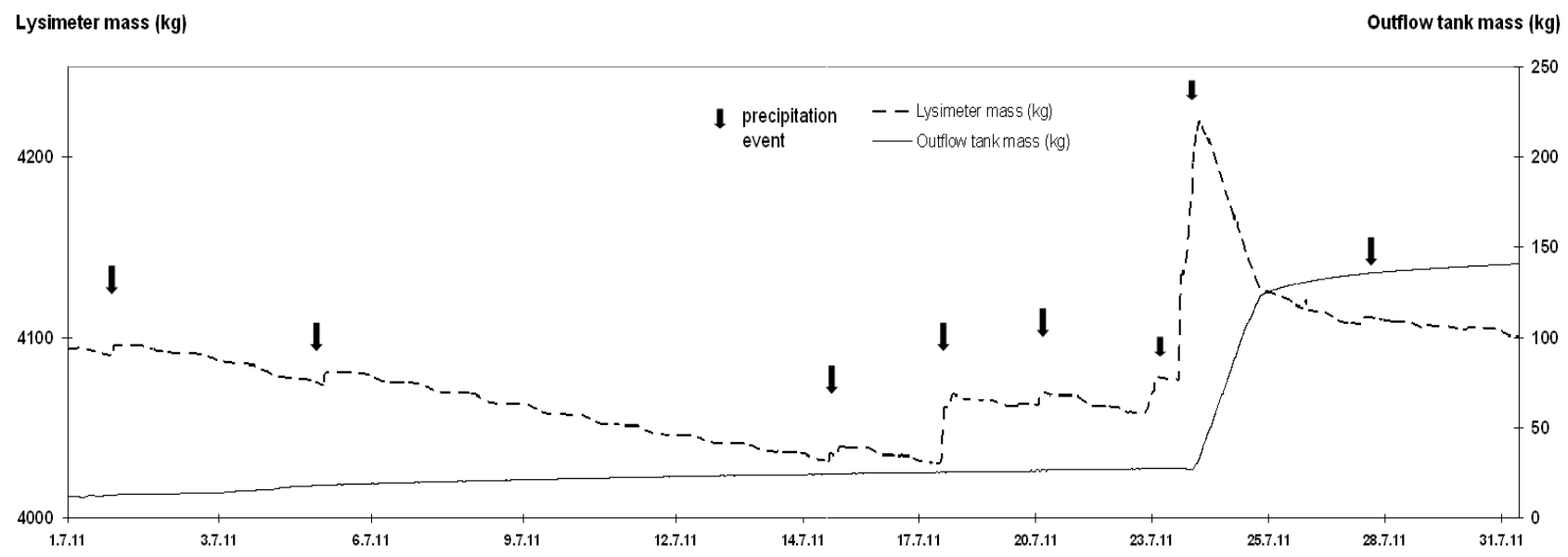

Figure 2: Mass of lysimeter $(\mathrm{kg})$ and outflow tank $(\mathrm{kg})$ for lysimeter station in Kleče in July 2011, black arrows mark precipitation events 
Table 2: Water balance parameters: mass change of lysimeter $d W_{7 h}$ and outflow tank $d O_{7 h}$, precipitation measured by ARSO in the city $P_{\text {city }}$ and on the site $P_{\text {site }}$, and $P_{l y s}$ as determined from $W$ data, $E T_{0}$ and $E T_{a}$ calculated from Eq. 2 using $P_{\text {lys }}$

\begin{tabular}{|c|c|c|c|c|c|c|c|}
\hline Date & $d W_{7 h}(\mathrm{~mm})$ & $d O_{7 h}(\mathrm{~mm})$ & $P_{\text {city }}(\mathrm{mm})$ & $P_{\text {site }}(\mathrm{mm})$ & $P_{l y s}(\mathrm{~mm})$ & $E T_{0}(\mathrm{~mm})$ & $E T_{a}(\mathrm{~mm})$ \\
\hline 1.7 .2011 & 1.3 & 1.7 & & & 5.8 & 3.8 & 2.9 \\
\hline 2.7 .2011 & -4.5 & 0.6 & 4.2 & 5.6 & & 4.1 & 3.9 \\
\hline 3.7 .2011 & -5.9 & 1.5 & & & & 5.1 & 4.5 \\
\hline 4.7.2011 & -7.9 & 2.5 & & & & 5.9 & 5.4 \\
\hline 5.7 .2011 & 3.2 & 1.3 & & & 8.0 & 4.2 & 3.4 \\
\hline 6.7 .2011 & -5.5 & 0.9 & 10.3 & 7.4 & 0.2 & 5.0 & 4.8 \\
\hline 7.7 .2011 & -5.9 & 0.8 & & & & 5.8 & 5.0 \\
\hline 8.7 .2011 & -6.0 & 0.7 & & & 0.1 & 6.2 & 5.4 \\
\hline 9.7 .2011 & -6.0 & 0.8 & & & & 6.2 & 5.2 \\
\hline 10.7.2011 & -5.9 & 0.7 & & & & 6.5 & 5.2 \\
\hline 11.7 .2011 & -5.2 & 0.5 & & & & 6.1 & 4.8 \\
\hline 12.7 .2011 & -4.8 & 0.7 & & & & 5.4 & 4.1 \\
\hline 13.7.2011 & -4.9 & 0.3 & & & & 5.7 & 4.6 \\
\hline 14.7.2011 & -4.7 & 0.4 & & & & 5.9 & 4.3 \\
\hline 15.7.2011 & 7.3 & 0.4 & & & 10.3 & 3.0 & 2.6 \\
\hline 16.7.2011 & -4.3 & 0.4 & 7.4 & 7.8 & & 4.3 & 4.0 \\
\hline 17.7.2011 & 27.1 & 0.2 & & & 31.0 & 5.2 & 3.7 \\
\hline 18.7.2011 & 3.9 & 0.4 & 21.8 & 28.0 & 6.8 & 3.9 & 2.5 \\
\hline 19.7.2011 & -2.0 & 0.2 & 4.5 & 6.6 & & 4.0 & 1.7 \\
\hline 20.7 .2011 & 4.3 & 0.2 & 1.3 & 1.8 & 8.9 & 3.5 & 4.4 \\
\hline 21.7 .2011 & -6.2 & 0.4 & 6.5 & 6.6 & & 5.5 & 5.8 \\
\hline 22.7 .2011 & 13.1 & 0.3 & & & 17.6 & 4.7 & 4.1 \\
\hline 23.7 .2011 & 140.9 & 2.9 & 20.2 & - & 143.8 & 2.4 & 0.0 \\
\hline 24.7 .2011 & -57.4 & 64.4 & 65.5 & - & 4.7 & 1.7 & -2.3 \\
\hline 25.7 .2011 & -35.5 & 32.2 & 7.8 & - & & 2.1 & 3.3 \\
\hline 26.7 .2011 & -8.9 & 5.0 & & - & & 3.4 & 3.9 \\
\hline 27.7 .2011 & -2.7 & 3.1 & & - & 3.9 & 4.6 & 3.5 \\
\hline 28.7 .2011 & -3.0 & 2.0 & 5.2 & - & 0.5 & 2.3 & 1.4 \\
\hline 29.7 .2011 & -2.4 & 1.4 & 0.5 & - & 2.3 & 3.6 & 3.3 \\
\hline 30.7 .2011 & -1.0 & 1.4 & 0.8 & - & 2.6 & 3.3 & 2.1 \\
\hline 31.7 .2011 & -4.7 & 0.9 & 1.2 & - & & 3.4 & 3.9 \\
\hline Sum & 5.8 & -129.1 & 157.2 & * & 246.5 & 136.8 & 111.5 \\
\hline
\end{tabular}


Sensors for monitoring water status inside the lysimeter showed high soil water content (SWC) in 50 and $100 \mathrm{~cm}$ depth (Figure 3). $\mathrm{SWC}$ in $50 \mathrm{~cm}$ decreased slightly until rainfall from $22^{\text {nd }}$ onwards. Neither previous rainfall events nor characteristics of plant water uptake - usually expressed as stepwise decrease of SWC representing typical day-night-effects were displayed. It can be concluded that higher soil water dynamics occurred in the upper soil layer and the rooting zone, respectively. Decrease of SWC in $50 \mathrm{~cm}$ can be explained by water movement to upper soil layers compensating ET losses, or water flow to deeper layers, mainly due to gravitation forces. This question cannot be explained satisfactorily without information on water potential in the respective soil layers. SWC in 100 and $150 \mathrm{~cm}$ did not change visibly until rainfall from $22^{\text {nd }}$ onwards (Figure 3), however, downward water fluxes must be assumed, because of the constant outflow at the bottom boundary (Figure 2). Low SWC (between 6 and $9 \%$ ) of the $150 \mathrm{~cm}$ layer indicates poor water retention capacity (Figure
3), typical for gravely soils found on Ljubljana aquifer (Vižintin et al., 2009). The spike in SWC after $24^{\text {th }}$ of July for $36 \mathrm{hrs}$ represented water from rainfall moving towards outflow.

Measurements of the soil water tension in $190 \mathrm{~cm}$ depth inside the lysimeter and in the field (Figure 4) showed unsaturated conditions in the lysimeter and in the field (between -9 and $-20 \mathrm{hPa}$ ). During high precipitation between $22^{\text {nd }}$ and $24^{\text {th }}$ of July the outflow through the suction cups at the bottom of the lysimeter was not sufficiently fast to match the flow of the water through the soil layers outside in the field conditions, causing temporary water logging of the lower layers, expressed as positive water pressure $25 \mathrm{hPa}$ in the lysimeter (Figure 4). Water pressure in $190 \mathrm{~cm}$ in the field remained negative $(-3 \mathrm{hPa}$, Figure 4), indicating that the water flow following the storm did not saturate the lower layers but has moved through the gravelly sediments in a few hours.

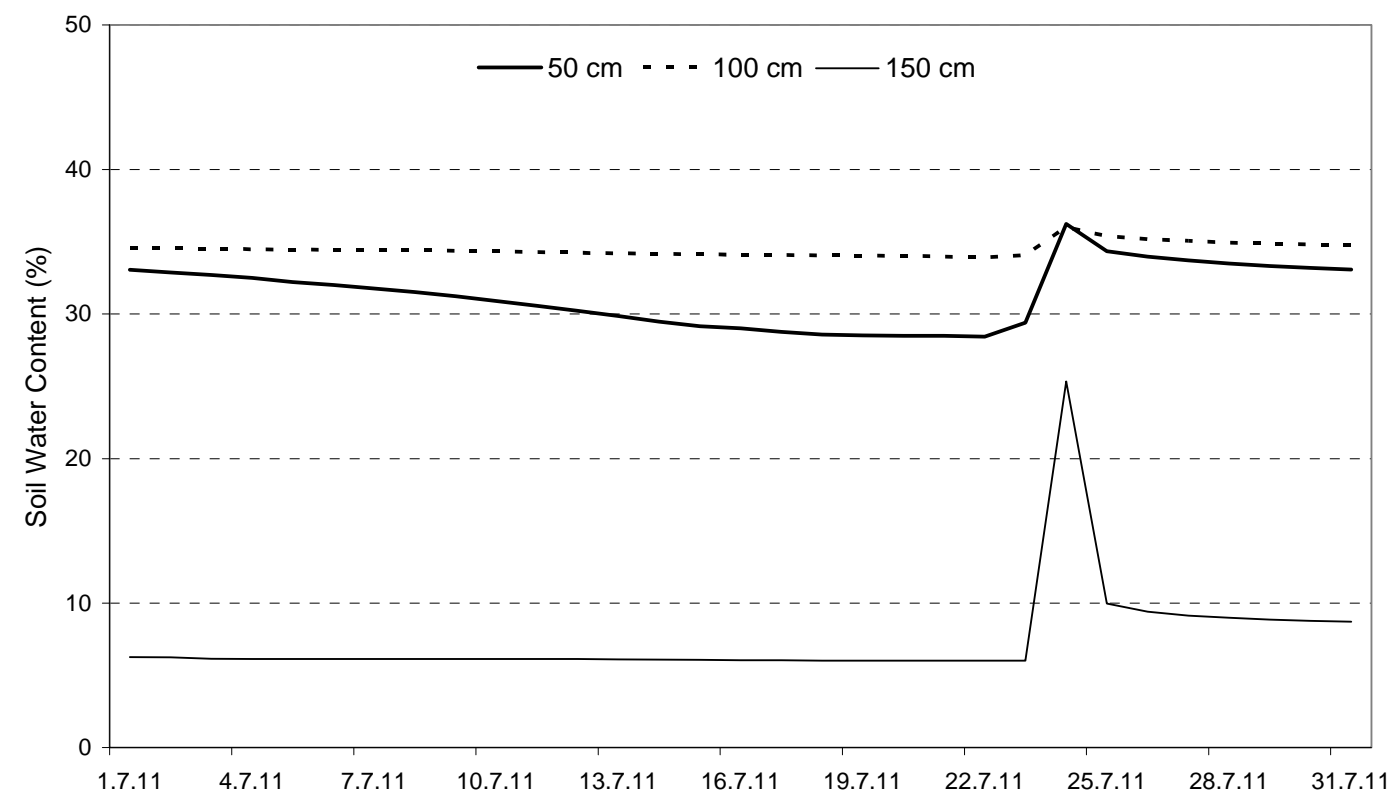

Figure 3: Soil water content (\%) in three soil depths $(50,100$ and $150 \mathrm{~cm})$ inside the Kleče lysimeter measured by TDR-probes in July 2011 


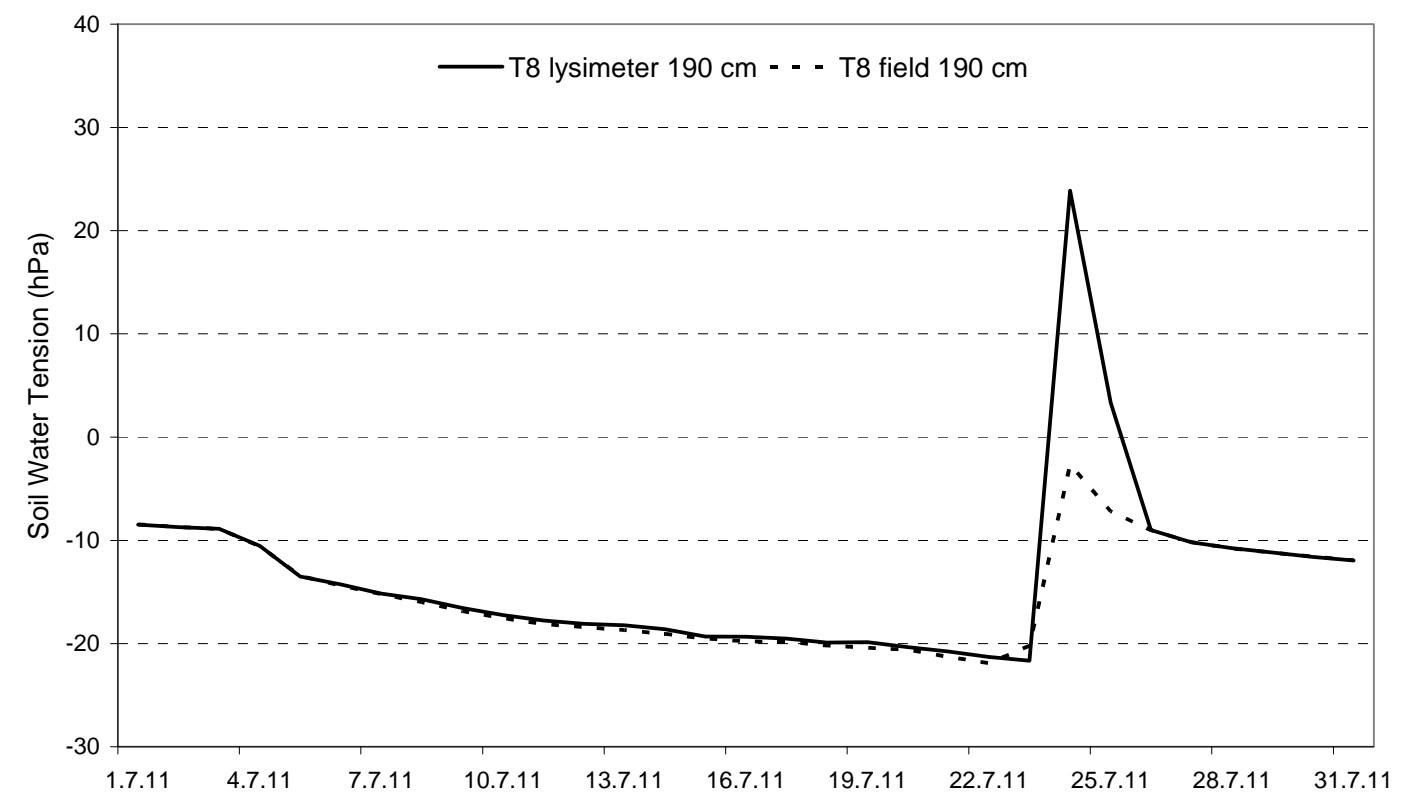

Figure 4: Soil water tension $(\mathrm{hPa})$ in $190 \mathrm{~cm}$ depth inside the Kleče lysimeter and in the field for boundary conditions management in July 2011

Only short period was evaluated, however the chosen month demonstrates weather extremes of the local climate - relatively dry periods, followed by high precipitation amount. In time of high plant water requirements only subsequent substantial precipitation events directly results in water flow towards lower layers. At the same time, the stony, gravelly layers of the deeper parts of the sediments have little or no capacity for water retention, and in the event that water line leaves top soil, water flow moves downwards fairly quickly. On one hand this confirms high recharge capacity of Ljubljansko polje aquifer from precipitation (Vižintin et al., 2009) on green areas; on the other hand it shows tremendous susceptibility of the aquifer to pollution and reinforces the position of groundwater protection zones above aquifer.

\section{CONCLUSIONS}

Practical execution of the commonly applied water balance equation is not as straightforward. Precipitation measurement in the same time resolution as the lysimeter mass measurements is needed for correct calculation of reference evapotranspiration. It is also possible that the outflow rate, which is determined by water flow through suction cups by pump activity, should be re-set. The results show that in time of high plant water requirements only substantial precipitation events directly contribute to immediate groundwater recharge as well as susceptibility of the aquifer of Ljubjansko polje to ground water pollution. 


\section{ACKNOWLEDGEMENTS}

Authors thank the reviewers for their constructive remarks, which helped improve the quality of the manuscript.

This work was partly funded by Austrian agency for international mobility and cooperation in education, science and research (OeAD) and Slovenian Research Agency in bilateral cooperation project BI-AT 11-12-024 - Comparison of data management for selected lysimeter stations in Slovenia and Austria.

\section{REFERENCES}

Allen R.G., Pereira L.S., Raes D., Smith, M. 1998. Crop Evapotranspiration: Guidelines for computing crop water requirements. Irrigation and Drainage Paper 56, Food and Agriculture Organization of the United Nations, Rome, 300 p.

Allen R.G., Pereira L.S., Howell T.A., Jensen M.E 2011. Evapotranspiration information reporting: I. Factors governing measurement Accuracy: review. Agricultural Water Management, 98: 899-920

Barros A.P., Lettenmaier D.P. 1994. Dynamic modeling of orographically induced precipitation. Reviews of geophysics, 32 (3): 265-284

Brilly M., Gorišek M 1985: Matematični model podtalnice Ljubljanskega barja : II. faza raziskave podtalne vode na Ljubljanskem barju, Ljubljana: FAGG, Laboratorij za mehaniko tekočin (in Slovenian)

Meissner R., Seeger J., Rupp H. 1998. Lysimeter studies in East Germany concerning the influence of set aside of intensively farmed land on the seepage water quality. Agriculture, Ecosystems and Environment, 67: 161-173

Meissner R., Seeger J., Rupp H., Seyfarth M., Borg H. 2007. Measurement of dew, fog, and rime with a high precision gravitation Lysimeter. Journal of Plant Nutrition and Soil Science, 170, 335-344

Vižintin G., Souvent P., Veselič M., Cencur Curk B. 2009. Determination of urban groundwater pollution in alluvial aquifer using linked process models considering urban water cycle. Journal of Hydrology, 377, 3-4: 261-273

Von Unold G., Fank J. 2008. Modular Design of Field Lysimeters for Specific Application Needs. Water Air Soil Pollut: Focus 8: 233-242

Xiao H., Meissner R., Seeger J., Rupp H., Borg H. 2009. Effect of vegetation type and growth stage on dewfall, determined with high precision weighing lysimeters at a site in northern Germany. Journal of Hydrology 377: 43-49

Young M.H., Wierenga P.J., Mancino C.F. 1996. Large weighing lysimeters for water use and deep percolation studies. Soil Science, 161: 491-501

Zupanc V., Bračič-Železnik B., Pintar M. 2005. Water balance assessment for lysimeter station based on Water Pumping Station Kleče in Ljubljana. Acta agric. Slov.. 85 (1), 83-90.

Zupanc V., Šturm M., Lojen S., Maršić-Kacjan N., AduGyamfi J., Bračič-Železnik B., Urbanc J., Pintar M. 2011. Nitrate leaching under vegetable field above a shallow aquifer in Slovenia. Agriculture, Ecosystems \& Environment, 144, 1: 167-174

Žagar M., Pristov N., Rakovec J. 2004. A diagnostic method for high-resolution precipitation prediction using dynamically adapted vertical velocities. Meteorol Atmos Phys 85, 187-204 